\title{
Impact of Different Sources of Organic Nutrients on Chemical Composition of S-36 Mulberry and Soil under Irrigated Condition
}

\author{
K.R. Shashidhar ${ }^{*}$, T.K. Narayanaswamy ${ }^{2}$, S.N. Sudhakar ${ }^{2}$ and R.N. Bhaskar ${ }^{2}$ \\ ${ }^{1}$ ICAR-Krishi Vigyan Kendra, Kolar, Karnataka, India \\ ${ }^{2}$ Department of Sericulture, University of Agricultural Sciences, Bangalore, Karnataka, India \\ *Corresponding author
}

A B S T R A C T

\begin{abstract}
Keywords
Green manures,

Oilcakes,

Vermicompost,

Microbial inoculants,

Chemical fertilizers

Article Info

Accepted:

16 December 2017

Available Online:

10 January 2018

The effect of different kinds of organic nutrients on biochemical composition of mulberry and soil status of S-36 mulberry garden was assessed. The pooled data of two crops revealed that mulberry raised with $100 \%$ Recommended N through $20 \%$ each of Compost + Glyricidia maculate + Castorcake + Vermicompost and Urea $+10 \mathrm{~kg}$ each of Azospirillum brasilense + Aspergillus awamori Bio-fertilizer + remaining $\mathrm{P}, \mathrm{K}$ through chemical fertilizers + Rec. FYM (T8) recorded significantly higher chemical composition of leaf viz., leaf nitrogen (3.31\%), phosphorous (1.69 \%), potassium (1.39\%), calcium $(2.96 \%)$, magnesium $(0.60 \%)$ and sulphur $(0.37 \%)$. Further, increased availability of nitrogen $(283.72 \mathrm{~kg} / \mathrm{ha})$, phosphorus $(79.75 \mathrm{~kg} / \mathrm{ha})$, potassium $(259.49 \mathrm{~kg} / \mathrm{ha})$, exchangeable calcium $(5.53 \mathrm{C}$. $\mathrm{mol} / \mathrm{kg})$, exchangeable magnesium $(4.26 \mathrm{C} . \mathrm{mol} / \mathrm{kg})$ and available sulphur $(37.85 \mathrm{~kg} / \mathrm{ha})$ contents of soil were also noticed in T8 treated plots compared to other treatments.
\end{abstract}

\section{Introduction}

Organic sources of nutrients are a key factor for soil fertility and productivity. Maintenance of soil organic matter at a satisfactory level is necessary. Recent days the chemical fertilizers are becoming costlier and scarce availability of commodities. Mulberry (Morus indica L.) is a deep rooted fast growing foliage crop of commercial importance, which produces leaves continuously throughout the year for rearing silkworm (Bombyx mori L.). Mulberry leaf productivity is highly dependent on plant nutrients like NPK and is known to respond well to the addition of organic manures
(Narayanaswamy et al., 2006). Organic manures plays an important role in building up soil fertility and increasing moisture holding capacity and growth of micro-organisms in the soil (Kerenhap et al., 2007). Introduction of crop benefiting microbial inoculants in to soil play a significant role in the mobilization of various nutrients needed by the crop. Application of microbial inoculants in conjunction with organic manures has significantly increased the productivity of mulberry leaf (Rashmi et al., 2007). In this context, supply of major nutrients to mulberry through organic manures and biofertilizers is highly imperative. With this background the 
present investigation was carried out to know the effect of major nutrients supplied through organic sources on chemical composition of mulberry and soil fertility status of S-36 mulberry garden under irrigated condition.

\section{Materials and Methods}

A field experiment was carried out in established irrigated S-36 mulberry garden planted at a spacing of $60 \mathrm{~cm} \times 60 \mathrm{~cm}$. The experiment was laid out in a Randomized Complete Block Design with 10 treatments of 3 replications each. The soil analysis report before the commencement of experiment revealed that, the soil is neutral in $\mathrm{pH}(7.1)$ and free from excessive salts $\left(0.04 \mathrm{dSm}^{-1}\right)$.

It is medium in organic carbon $(0.60 \%)$ and available nitrogen $(200 \mathrm{~kg} / \mathrm{ha})$, high in $\mathrm{P}_{2} \mathrm{O}_{5}$ $(50 \mathrm{~kg} / \mathrm{ha})$ and low in available $\mathrm{K}_{2} \mathrm{O}$ (86 $\mathrm{kg} / \mathrm{ha}$ ) were recorded before imposing the treatments. All cultivation practices for mulberry cultivation were followed as suggested by Dandin et al., (2003). The different sources of nitrogen through organic and inorganic fertilizers were applied in two split doses. The treatments were as follows,

T1: $100 \%$ Recommended 'N' through Glyricidia maculata $+10 \mathrm{~kg}$ each of Azospirillum brasilense + Aspergillus awamori Bio-fertilizer + Rec. P, K through chemical fertilizers + Rec. FYM

T2: $100 \%$ Recommended 'N' through Sunhemp $+10 \mathrm{~kg}$ each of Azospirillum brasilense + Aspergillus awamori Biofertilizer + Rec. P, K through chemical fertilizers + Rec. FYM

T3: $100 \%$ Recommended ' $\mathrm{N}$ ' through Pongamia leaves $+10 \mathrm{~kg}$ each of Azospirillum brasilense + Aspergillus awamori Biofertilizer + Rec. P, K through chemical fertilizers + Rec. FYM
T4: $100 \%$ Recommended 'N' through Castorcake $+10 \mathrm{~kg}$ each of Azospirillum brasilense + Aspergillus awamori Biofertilizer + Rec. P, K through fertilizers + Rec. FYM

T5: $100 \%$ Recommended ' $\mathrm{N}$ ' through Neemcake $+10 \mathrm{~kg}$ each of Azospirillum brasilense + Aspergillus awamori Biofertilizer + Rec. P, K through chemical fertilizers + Rec. FYM

T6: $100 \%$ Recommended 'N' through Pongamiacake $+10 \mathrm{~kg}$ each of Azospirillum brasilense + Aspergillus awamori Biofertilizer + Rec. $\mathrm{P}, \mathrm{K}$ through chemical fertilizers + Rec. FYM

T7: $100 \%$ Recommended 'N' through Compost $+10 \mathrm{~kg}$ each of Azospirillum brasilense + Aspergillus awamori Biofertilizer + Rec. $\mathrm{P}, \mathrm{K}$ through chemical fertilizers + Rec. FYM

T8: $100 \%$ Recommended 'N' through $20 \%$ each of Compost + Glyricidia maculata + Castorcake + vermicompost and Urea $+10 \mathrm{~kg}$ each of Azospirillum brasilense + Aspergillus awamori Bio-fertilizer.+ remaining $\mathrm{P}, \mathrm{K}$ through chemical fertilizers + Rec. FYM

T9: Recommended 40 tonnes FYM / ha / year + 225: 150: $150 \mathrm{~N}, \mathrm{P}$ and $\mathrm{K} \mathrm{kg} \mathrm{/} \mathrm{ha} \mathrm{/} \mathrm{year}$ through chemical fertilizer (control).

T10: $10 \mathrm{~kg}$ each of Azospirillum brasilense + Aspergillus awamori Bio-fertilizer + Recommended 40 tonnes FYM / ha / year + 225: 150: $150 \mathrm{~N}, \mathrm{P}$ and $\mathrm{K} \mathrm{kg} \mathrm{/} \mathrm{ha} \mathrm{/} \mathrm{year}$ through chemical fertilizer.

The biofertilizers viz., Azospirillum brasilense and Aspergillus awamori were incorporated into the soil along with FYM ten days after application of organic manures and inorganic fertilizers. The $\mathrm{P}$ and $\mathrm{K}$ nutrients supplied in 
the form of Single Super Phosphate (SSP) and Muriate of Potash (MoP) respectively for all treatments. The leaf samples of $\mathrm{S}_{36}$ mulberry collected from labelled plants on 60th day of II and IV crops were oven dried at 65 to $70^{\circ} \mathrm{C}$ for $48 \mathrm{hrs}$ and then made into fine powdered in Wiley mill (Stainless steel wheels), after grinding dry again at $70^{\circ} \mathrm{C}$ to remove the moisture then preserved in butter paper/polythene cover and used for chemical analysis. The nitrogen estimation was carried out by Microkjeldahl method (A.O.A.C., 1980), the phosphorous and sulphur were estimated by the method outlined (Jackson, 1973), Calcium and magnesium were determined by the EDTA titration method. Further, the available nitrogen in soil was estimated by alkaline potassium permanganate method (Subbaiah and Asija, 1956), available phosphorous by Bray's No.1 method, available potassium by Flame photometer method, available calcium and magnesium by Versanate titration method and available sulphur by Turbidometric method as per the procedure outlined by Jackson, (1973). The data was analysed statistically by using simple randomized complete block design (RCBD) as outlined by Cochran and Cox, (2000).

\section{Results and Discussion}

\section{Chemical composition of S-36 mulberry garden soil}

Significant improvement was observed in soil fertility due to imposition of different organic manures, bioinoculants and chemical fertilizers (Table 1). The availability of soil N, $\mathrm{P}, \mathrm{K}, \mathrm{Ca}, \mathrm{Mg}$ and $\mathrm{S}$ in the mulberry garden was increased due to combined application of $100 \%$ Recommended N through $20 \%$ each of Compost + Glyricidia maculata + Castorcake (CC) + Vermicompost (VC) and Urea $+10 \mathrm{~kg}$ each of Azospirillum brasilense + Aspergillus awamori Bio-fertilizer + remaining $\mathrm{P}, \mathrm{K}$ through chemical fertilizers + Rec. FYM (T8) which recorded maximum available $\mathrm{N}$ (283.72 $\mathrm{kg} / \mathrm{ha}), \mathrm{P}(79.75 \mathrm{~kg} / \mathrm{ha}), \mathrm{K}(259.49 \mathrm{~kg} / \mathrm{ha})$, Exchangeable calcium (5.53 C. $\mathrm{mol} / \mathrm{kg})$, Exchangeable magnesium (4.26 C. $\mathrm{mol} / \mathrm{kg}$ ) and available sulphur $(37.85 \mathrm{~kg} / \mathrm{ha})$ followed by T10 which recorded availability of soil $\mathrm{N}$, $\mathrm{P}, \mathrm{K}, \mathrm{Ca}, \mathrm{Mg}$ and $\mathrm{S}$ content $(278.23 \mathrm{~kg} / \mathrm{ha}$, $77.89 \mathrm{~kg} / \mathrm{ha}, 255.37 \mathrm{~kg} / \mathrm{ha}, 5.45$ C.mol / Kg, $4.21 \mathrm{C} . \mathrm{mol} / \mathrm{Kg}$ and $36.53 \mathrm{Kg} / \mathrm{ha}$ ) respectively. Similarly, the lowest available N (208.04 $\mathrm{kg} / \mathrm{ha}), \mathrm{P}$ (59.30 kg/ha), K (214.74 kg/ha), Exchangeable calcium (4.47 C. $\mathrm{mol} / \mathrm{kg})$, Exchangeable magnesium (3.41 C. $\mathrm{mol} / \mathrm{kg}$ ) and available sulphur $(25.40 \mathrm{~kg} / \mathrm{ha})$ was found in $100 \%$ Recommended $\mathrm{N}$ through Neemcake $+10 \mathrm{~kg}$ each of Azospirillum brasilense + Aspergillus awamori Bio-fertilizer + Rec. P, K through chemical fertilizers + Rec. FYM (T5) treated soil. The increased availability of NPK in soil may be attributed to better nitrogen fixing capacity of Azospirillum brasilense, $\mathrm{P}$ solubilization and mobilization by $A$. awamori and in presence of FYM, vermicompost, green manure and oilcakes and inorganic fertilizers. Similarly, Sori et al., (2008) the mulberry gardens treated with bio-inoculants at $20 \mathrm{~kg} / \mathrm{ha}$ of Azotobacter $+25 \mathrm{~kg} / \mathrm{ha}$ of A. awamori +20 $\mathrm{kg} / \mathrm{ha}$ of $T$. harzianum +75 per cent recommended nitrogen and phosphorous each through chemical fertilizer with full recommended dose of FYM and $\mathrm{K}$ has recorded maximum available NPK. The result was in agreement with the findings of many researchers (Rashmi et al., 2007; Chikkaswamy, 2015).

\section{Biochemical composition of S-36 mulberry leaf}

\section{NPK percentage in $S_{36}$ mulberry leaves}

Macro nutrient status in $\mathrm{S}_{36}$ mulberry leaves was significantly influenced by application of organic manures, bio-inoculants and inorganic fertilizers (Table 2). 
Table.1 Nutrient status of $S_{36}$ mulberry garden soil as influenced by different sources of organic nutrients

\begin{tabular}{|c|c|c|c|c|c|c|}
\hline Treatments & $\begin{array}{c}\text { A vailable } \\
\text { Nitrogen (Kg } \\
\text { /ha) }\end{array}$ & $\begin{array}{c}\text { Available } \\
\text { Phosphorus (Kg /ha) }\end{array}$ & $\begin{array}{c}\text { Available } \\
\text { Potassium (Kg /ha) }\end{array}$ & $\begin{array}{c}\text { Exchangeable } \\
\text { Calcium (C. mol/kg) }\end{array}$ & $\begin{array}{c}\text { Exchangeable } \\
\text { Magnesium (C. } \\
\text { mol/kg) }\end{array}$ & $\begin{array}{c}\text { Available } \\
\text { Sulphur (Kg } \\
\text { /ha) }\end{array}$ \\
\hline $\mathbf{T}_{1}$ & 213.77 & 61.41 & 229.29 & 4.71 & 3.94 & 29.52 \\
\hline$T_{2}$ & 214.28 & 62.89 & 235.72 & 4.99 & 3.99 & 27.53 \\
\hline$\overline{T_{3}}$ & 210.38 & 60.65 & 219.59 & 4.81 & 3.49 & 26.63 \\
\hline$T_{4}$ & 216.95 & 68.01 & 235.41 & 5.04 & 3.96 & 29.53 \\
\hline $\mathbf{T}_{5}$ & 208.04 & 59.30 & 214.74 & 4.47 & 3.41 & 25.40 \\
\hline$T_{6}$ & 213.49 & 64.93 & 230.40 & 4.91 & 3.91 & 27.54 \\
\hline $\mathbf{T}_{7}$ & 254.51 & 63.71 & 241.89 & 5.12 & 4.07 & 31.03 \\
\hline $\mathrm{T}_{8}$ & 283.72 & 79.75 & 259.49 & 5.53 & 4.26 & 37.85 \\
\hline $\mathrm{T}_{9}$ & 275.42 & 76.65 & 253.66 & 5.42 & 4.17 & 34.07 \\
\hline$T_{10}$ & 278.23 & 77.89 & 255.37 & 5.45 & 4.21 & 36.53 \\
\hline F - Test & $*$ & $*$ & * & $*$ & $*$ & $*$ \\
\hline S. Em \pm & 0.62 & 0.33 & 1.51 & 0.16 & 0.06 & 0.10 \\
\hline C.D@ @ 9 & 1.87 & 1.01 & 4.53 & 0.48 & 0.18 & 0.32 \\
\hline
\end{tabular}

*significant

Table.2 Leaf chemical composition of $\mathrm{S}_{36}$ mulberry as influenced by different sources of organic nutrients

\begin{tabular}{|c|c|c|c|c|c|c|}
\hline Treatments & Nitrogen (\%) & Phosphorus (\%) & Potassium (\%) & Calcium (\%) & Magnesium (\%) & Sulphur (\%) \\
\hline$T_{1}$ & 3.10 & 1.53 & 1.12 & 2.66 & 0.51 & 0.31 \\
\hline$T_{2}$ & 3.08 & 1.55 & 1.19 & 2.68 & 0.53 & 0.32 \\
\hline$T_{3}$ & 2.99 & 1.45 & 1.05 & 2.57 & 0.47 & 0.27 \\
\hline $\mathbf{T}_{4}$ & 3.12 & 1.54 & 1.15 & 2.67 & 0.53 & 0.32 \\
\hline $\mathrm{T}_{5}$ & 2.92 & 1.40 & 1.00 & 2.51 & 0.44 & 0.27 \\
\hline$T_{6}$ & 3.08 & 1.54 & 1.13 & 2.59 & 0.49 & 0.31 \\
\hline $\mathrm{T}_{7}$ & 3.05 & 1.59 & 1.11 & 2.59 & 0.51 & 0.31 \\
\hline $\mathrm{T}_{8}$ & 3.31 & 1.69 & 1.39 & 2.96 & 0.60 & 0.37 \\
\hline $\mathrm{T}_{9}$ & 3.24 & 1.61 & 1.28 & 2.90 & 0.57 & 0.34 \\
\hline$T_{10}$ & 3.26 & 1.65 & 1.32 & 2.93 & 0.58 & 0.36 \\
\hline F - Test & $*$ & $*$ & $*$ & $*$ & $*$ & $*$ \\
\hline S. Em \pm & 0.02 & 0.02 & 0.01 & 0.01 & 0.02 & 0.02 \\
\hline C.D @ 5\% & 0.06 & 0.06 & 0.03 & 0.04 & 0.07 & 0.06 \\
\hline
\end{tabular}

*significant 
The maximum leaf nitrogen, phosphorous and potassium contents of $3.31,1.69$ and 1.39 per cent respectively was recorded when $S_{36}$ mulberry plots received $100 \%$ Recommended $\mathrm{N}$ through $20 \%$ each of Compost + Glyricidia maculata + Castorcake (CC) + Vermicompost (VC) and Urea $+10 \mathrm{~kg}$ each of Azospirillum brasilense + Aspergillus awamori Bio-fertilizer + remaining $\mathrm{P}, \mathrm{K}$ through chemical fertilizers $\left(\mathrm{T}_{8}\right)$, which was followed by $\mathrm{T}_{10}(3.26,1.65$ and $1.32 \%)$ and $\mathrm{T}_{9}(3.24,1.61$ and $1.28 \%) \mathrm{NPK}$, respectively. Increased nitrogen and phosphorus contents of leaf may be due to increased availability of nitrogen and phosphorus in soil due to application of different sources of organic manures as a source of nitrogen in addition to application of $\mathrm{N}$-fixing biofertilizers like Azospirillum brasilanse and Aspergillus awamori, a phosphorus solubilizing fungus might help in releasing the phosphorus. These results are in agreement with results obtained by Rashmi et al., (2007) increased uptake of NPK by $S_{36}$ and $M_{5}$ mulberry as a result of integration of biofertilizers with different organic manures and inorganic fertilizers which in turn led to better availability and absorption of the nutrients to plant system and its translocation to leaves. Further, Chikkaswamy (2015) reported that among different Cynobacterial biofertilizer treatment, T9 $(\mathrm{Av}+\mathrm{Nm}+\mathrm{Sm}(120 \mathrm{~kg} / \mathrm{ha} / \mathrm{crop})$ $+50 \% \mathrm{NPK}$ ) exhibited superior performance with regard to leaf quality traits and was on par with control (100\% NPK).The result was in agreement with the findings of many researchers (Umesha and Sannappa 2014; Reddy et al., 2003;Sori et al., 2008).

\section{Ca, $M g$ and $S$ contents of $S_{36}$ mulberry}

Secondary nutrients viz., calcium, magnesium and sulphur content of $S_{36}$ mulberry leaves were significantly influenced by the organic based nutrient management (Table 2).

Among the treatments, significantly higher calcium content $(2.96 \%)$, magnesium $(0.60 \%)$ and sulphur $(0.37 \%)$ content were recorded in mulberry grown with $100 \%$ Recommended N through $20 \%$ each of Compost + Glyricidia maculata + Castorcake (CC) + Vermicompost (VC) and Urea $+10 \mathrm{~kg}$ each of Azospirillum brasilense + Aspergillus awamori Bio-fertilizer + remaining $\mathrm{P}, \mathrm{K}$ through chemical fertilizers $\left(\mathrm{T}_{8}\right)$.

The increased $\mathrm{Ca}, \mathrm{Mg}$ and $\mathrm{S}$ contents in combined application of different types of organic manures, biofertilizers and inorganic fertilizers applied plots clearly suggests that oilcakes and vermicompost are rich in NPK, micronutrients and enzymes, thus promoting the maximum growth of mulberry which in turn improves the quality of leaves (Reddy et al., 2003). According to Ramakrishna Naika (2008) the secondary nutrient status of $\mathrm{V}_{1}$ mulberry leaves differed significantly higher being with enriched vermicompost $(100 \% \quad \mathrm{~N})+$ recommended $\mathrm{P}$ and $\mathrm{K}$ for calcium and magnesium, while sulphur was more with both vermicompost $(100 \% \mathrm{~N})+$ recommended $\mathrm{P}$ and $\mathrm{K}$ and enriched vermicompost $(100 \% \mathrm{~N})+$ recommended $\mathrm{P}$ and $\mathrm{K}$ over rest of the sources of organic manures. The result was in agreement with the findings of many researchers (Rashmi et al., 2007; Chikkaswamy, 2015).

From the above findings it is concluded that, application of different organic manures and biofertilizers along with lower dose of fertilizers plays a significant role in enhancing the soil fertility in terms of macronutrients, secondary nutrients and microbial population.

The biofertilizers like $A$. brasilense and $A$. awamori helped in enriching the soil with the major nutrients like $\mathrm{N} P$ and $\mathrm{K}$ which are mainly essential for luxuriant growth of mulberry crop, which in turn led to better availability and absorption of the nutrients to plant system and its translocation to leaves.

\section{Acknowledgement}

The research investigation is part of the Ph. D. programme entitled "Organic based nutrient management in mulberry (Morus indica L.) and its influence on rearing performance of silkworm (Bombyx mori L.)". The financial help 
received from the Government of India and UAS Bangalore is greatly acknowledged.

\section{References}

Chikkaswamy, B. K. 2015. Effect of cynobacterial biofertilizer on soil nutrients and mulberry leaf quality and its impact on silkworm crops. Int.J.Adv.Res.Eng.Appl.Sci. 4(1): 1-15.

Chowdhury, P.K., Setua, G.C., Ghosh, A., Kar, R., and Maity, S.K. 2013. Sustainable quality leaf production in S-1635 mulberry (Morus alba) under irrigated condition through organic nutrient management. Indian J. Agricultural Sci., 83(5): 529-34.

Cochran and Cox, 2000. Experimental Design Procedures for the Behavioural Sciences. Cole Publishing Company, Pp. 319-380.

Dandin, S. B., Jayaswal, J., and Giridhar, K., 2003. Hand Book of Sericulture Technologies, Central Silk Board, Bangalore, Pp. 259.

Jackson, M.L. 1979. Soil Chemical Analysis: Advance Course. University of Wisconsin, Madison and Wisconsin.

Kerenhap, W., Thiagarajan, V., and Kumar, V. 2007. Biochemical and bioassay studies on the influence of different organic manures on the growth of Mulberry Variety V-1 and silkworm, Bombyx mori L. Caspian J. Env. Sci., 5(1): 51-56.

Narayanaswamy, T. K., Rajegowda, Shankar, M. A., and Sreeramulu, K. R. 2006. Effect of different organic manures on growth and yield parameters of M-5 and
S-36 mulberry varieties. Res. on Crops, 7(2): 541-543.

Ramakrishnanaika, 2008. Response of Victory1 mulberry to different sources of organic manures and their impact on silkworm growth and development. Ph.D. (Seri.) Thesis, UAS, Bangalore, p.210.

Rashmi, K., Shankar, M. A., Narayanaswamy, T. K., Sreeramulu, K. R., and Rajegowda. 2007. Impact of organic mulberry cultivation practices on soil microbes and fertility of M-5 mulberry garden. $J$. Ecobiology, 21: 113-116.

Reddy, B. K., Ramarao, D. M., Reddy, M. P., and Suryanarayana, N. 2003. Studies on the effect of farmyard manure and vermicompost on quantitative and qualitative characters of mulberry under semi-arid conditions of Andhra Pradesh. Adv. Plant Sci., 16(1): 177 - 182.

Sori, W., Bhaskar, R. N., Sudhir, K., Shashidhar, K. R., and Sarithakumari, S. 2008. Influence of Bio-inoculants on available $\mathrm{N}, \mathrm{P}$ and $\mathrm{K}$ content of $\mathrm{M}-5$ Mulberry garden under Rainfed Condition, Moriculture. (Eds. K. Jaiswal, S. P. Trivedi, B.N. Pandey and R. K. Khatri), APH Publishing Corporation, New Delhi, Pp. 165.

Subbiah, B.V., and Asija, G.L. 1956. A rapid procedure for the estimation of available nitrogen in soil. Curr. Sci., 25:259-61.

Umesha, A., and Sannappa, B. 2014. Biochemical and mineral constituents of mulberry leaf raised through organic based nutrients in red loamy soil. Int. J. Adv. Res., 2(9): 348-355.

\section{How to cite this article:}

Shashidhar, K.R., T.K. Narayanaswamy, S.N. Sudhakar and Bhaskar, R.N. 2018. Impact of Different Sources of Organic Nutrients on Chemical Composition of S-36 Mulberry and Soil under Irrigated Condition. Int.J.Curr.Microbiol.App.Sci. 7(01): 2233-2238.

doi: https://doi.org/10.20546/ijcmas.2018.701.269 